Int. J. Electrochem. Sci., 14 (2019) 11065 - 11080

International Journal of

ELECTROCHEMICAL

SCIENCE

www.electrochemsci.org

\title{
The Behaviour of Tribocorrosion on EH47 High-Strength Ship Hull Steel in a 3.5\% NaCl Solution
}

\author{
Hongmei Zhang ${ }^{1,2, *}$, Yan $\mathrm{Li}^{2}$, Na Li ${ }^{1}$, Ling Yan ${ }^{2}$, Yangyang Zhu ${ }^{1}$,Changshun Wang ${ }^{2}$, \\ Fangfang $A i^{2}$, Zhengyi Jiang ${ }^{1,3 *}$ \\ ${ }^{1}$ School of Material and Metallurgy, University of Science and Technology Liaoning, Anshan 114051, \\ China \\ ${ }^{2}$ State Key Laboratory of Metal Material for Marine Equipment and Application, Liaoning, Anshan, \\ 114009 \\ ${ }^{3}$ School of Mechanical, Materials and Mechatronic Engineering, University of Wollongong, \\ Wollongong NSW 2522, Australia \\ *E-mail: zhanghm@ustl.edu.cn, jiang@uow.edu.au
}

doi: $10.20964 / 2019.12 .65$

Received: 6 August 2019 / Accepted: 29 September 2019 / Published: 29 October 2019

In this paper, the tribocorrosion behaviour of $\mathrm{EH} 47$ high-strength ship hull steel in a $3.5 \% \mathrm{NaCl}$ solution was investigated. The tribological and corrosion tests were carried out on a $\mathrm{Si}_{3} \mathrm{~N}_{4}$ ball-onEH47 high-strength ship hull steel disc tribometer under different sliding time conditions. The disks were continuously immersed in sandy $3.5 \% \mathrm{NaCl}$ solution during the whole process of the tribological tests. After the tribological tests, electrochemical tests were carried out to obtain typical polarization curves and electrochemical impedance spectroscopy diagrams. The corrosion experiments were performed to investigate the effect of abrasion on corrosion behaviour by immersing the samples in a container with $3.5 \% \mathrm{NaCl}$ solution and $5 \mathrm{wt} . \%$ silica sand at room temperature for 7,14 , and 49 days. The micrographs, compositions and corrosion products of the worn scars were evaluated by scanning electron microscopy (SEM) and energy dispersive spectroscopy (EDS) microanalyses.

Keywords: Corrosion; Abrasion; Marine environment; Wear mechanism; Tribological tests

\section{$\underline{\text { FULL TEXT }}$}

(C) 2019 The Authors. Published by ESG (www.electrochemsci.org). This article is an open access article distributed under the terms and conditions of the Creative Commons Attribution license (http://creativecommons.org/licenses/by/4.0/). 